\title{
PENGARUH KUALITAS LAYANAN PADA WARUNG INTERNET \\ I-CAFE TERHADAP LOYALITAS PELANGGAN MELALUI \\ KEPUASAN PELANGGAN DI KOTA BLITAR
}

\author{
Efraim Honey P; Ariadi Santoso; Endang Girahani \\ Fakultas Ekonomi - Universitas Kadiri \\ E-mail : ariadi_santoso@unik-kediri.ac.id
}

\begin{abstract}
Today the competition in the business world is getting tighter. Including business competition in the business of providing internet services. Warnet I - Cafe in the City of Blitar is one of the service companies engaged in this business. Although getting many competitors from the same field, Warnet I - Cafe in Blitar City is still able to survive by carrying out various strategies. The purpose of this study is to determine and analyze the effect of Service Quality (X) on Customer Loyalty (Y). To find out and analyze the influence of Service Quality (X) on Customer Satisfaction (Z). To find out and analyze the influence of Customer Satisfaction (Z) on Customer Loyalty (Y). To find out and analyze the influence of Service Quality (X) on Customer Loyalty (Y) through Customer Satisfaction ( $\mathrm{Z})$ as an intervening variable. This type of research is explanatory research. This research was conducted at Warnet I - Cafe customers in Blitar City. The population in this study were all customers, male and female, and aged 17 to 25 years in March 2018 as many as infinite customers. The research sample totaled 93 respondents with purposive sampling sampling technique. The results showed that Service Quality had an effect on Customer Satisfaction at Warnet I - Cafe in Blitar City. Service Quality influences Customer Loyalty at Warnet I - Cafe in Blitar City. Customer Satisfaction influences Customer Loyalty at Warnet I - Cafe in Blitar City. Service Quality influences Customer Loyalty through Customer Satisfaction.
\end{abstract}

Keywords: Service Quality, Customer Loyalty, Customer Satisfaction

\begin{abstract}
ABSTRAK
Sekarang ini persaingan dunia usaha menjadi semakin ketat. Termasuk persaingan usaha dalam bidang bisnis penyediaan jasa internet. Warnet I - Cafe di Kota Blitar merupakan salah satu perusahaan jasa yang bergerak dalam bidang usaha tersebut. Walaupun mendapat banyak pesaing dari bidang yang sama, namun Warnet I - Cafe di Kota Blitar tetap mampu bertahan dengan melakukan berbagai strategi. Tujuan penelitian ini adalah Untuk mengetahui dan menganalisis pengaruh Kualitas Layanan (X) terhadap Loyalitas Pelanggan (Y). Untuk mengetahui dan menganalisis pengaruh Kualitas Layanan (X) terhadap Kepuasan Pelanggan (Z). Untuk mengetahui dan menganalisis pengaruh Kepuasan Pelanggan (Z) terhadap Loyalitas Pelanggan (Y). Untuk mengetahui dan menganalisis pengaruh Kualitas Layanan (X) terhadap Loyalitas Pelanggan (Y) dengan melalui Kepuasan Pelanggan (Z) sebagai variabel intervening. Jenis penelitian ini adalah eksplanatory research. Penelitian ini dilakukan di pelanggan Warnet I - Cafe di Kota Blitar. Populasi dalam penelitian ini adalah semua pelanggan, laki - laki dan perempuan, dan berumur 17 sampai 25 tahun pada bulan Maret 2018
\end{abstract}


sebanyak tidak terhingga pelanggan. sampel penelitian berjumlah 93 responden dengan teknik sampling purposive sampling. Hasil penelitian menunjukkan Kualitas Layanan berpengaruh terhadap Kepuasan Pelanggan di warnet I - Cafe di Kota Blitar. Kualitas Layanan berpengaruh terhadap Loyalitas Pelanggan di warnet I - Cafe di Kota Blitar. Kepuasan Pelanggan berpengaruh terhadap Loyalitas Pelanggan di warnet I - Cafe di Kota Blitar. Kualitas Layanan berpengaruh terhadap Loyalitas Pelanggan melalui Kepuasan Pelanggan.

Kata Kunci: Kualitas Layanan, Loyalitas Pelanggan, Kepuasan Pelanggan

\section{PENDAHULUAN}

Pada era yang sekarang ini, kita di sajikan dengan banyak kemajuan yang di sediakan mulai dari teknologi, pakaian dan fasilitas - fasitilas lainnya. Dalam hal ini yang saya ingin soroti adalah dalam hal teknologi, khususnya Internet. Dalam dunia serba digital saat ini, internet sudah menjadi kebutuhan setiap lapisan masyarakat, dengan keadaan yang seperti ini, warung internet adalah tempat yang sangat banyak di kunjungi para pelanggan, baik usia muda, remaja sampai dewasa (Ruhamak \& Rahayu, 2016). Dengan internet, masyarakat mampu berkomunikasi dengan mudah, dan cepat. Model - model tempat yang artristik dan nyaman untuk para konsumen Segala penilaian konsumen dalam menikmati kualitas layanan dapat mempengaruhi penilaian dari pelanggan tentang kepuasannya atau loyalitas suatu layanan (Kristanti, 2018; Satriyono \& Ruhamak, 2017). Dalam lingkungan yang kompetitif saat ini memberikan layanan berkualitas tinggi adalah kunci untuk keunggulan kompetitif yang berkelanjutan.

Kepuasan pelanggan memang memiliki efek positif pada profitabilitas organisasi (Biljana dan Yusuf, 2011:232). Usaha warnet I-Cafe di Kota Blitar ini bergerak di bidang jasa, usaha ini berfokus pada konsumen yang senang dengan dunia Game Online, dengan perkembangan yang saat ini, usaha ini sangat mengutamakan kualitas pelayanannya, baik pelayanan fisik maupun non fisik. Dengan demikian, mengangkat usaha ini untuk di teliti bagaimana mereka menjaga kualitas pelayanannya dan cara mereka mendapatkan loyalitas konsumenya ada hal yang sangat menarik dan memberi wawasan baru untuk para usaha - usaha muda lainnya.

Berkualitas jasa yang lebih baik ialah beberapa hal yang sangatlah terpenting didalam menciptakan kepuasan tersendiri kepada pelanggan, tetapi namun untuk memahami cara bagaimana mengevaluasinya berkualitas yang bisa diterima oleh beberapa konsumen tidaklah mudah (Munawaroh, 2005:120). bahwa berkualitas pelayanannya sangatlah penting dipertahankan untuk mendapatkan kepuasannya 
pelanggan. Pentingnya kepuasan dari pelanggan terkait erat dengan keberlangsungan perusahaan dan untuk pertumbuhan di masa yang akan datang yang lebih kuat (Sheu and Mei, 2005). Kepuasannya pelanggannya membentuk dasar-dasar dari setiap usaha atau bisnis yang lebih sukses sebagai kepuasan pelanggan terarah untuk mengulangi pembeliannya, loyalitas mereknya, dan kata-kata positif dari mulut ke mulut (Biljana dan Yusuf, 2011:232).

\section{TINJAUAN PUSTAKA}

\section{Landasan Teori}

\section{Warung Internet}

Oleh karena itu, tidak heran hingga saat ini WARNET diadopsi oleh masyarakat Indonesia. Menurut Gaganet (2010), Warnet adalah salah satu bentuk usaha yang dikelola oleh kelompok atau individu yang memberikan pelayanan dalam bentuk jasa internet oleh penggunanya.

Warung Internet adalah sebuah kata yang berkembang di antara para aktivis Internet Indonesia pada tahun 1997-1998 untuk sebuah kios yang memiliki banyak komputer untuk di sewakan bagi pengakses Internet. Pada masa itu, secara tidak sadar terjadi perebutan singkatan dari Warung Internet antara WARIN dan WARNET. Seharusnya jika kita konsisten dengan proses menyingkat kata, seperti WARTEG (Warung Tegal) dan WARTEL (Warung Telekomunikasi), maka yang seharusnya di pilih adalah WARIN.

Di era - era saat ini warnet adalah tempat dimana orang - orang mengakses internet. pada beberapa negara atau daerah maju, akses internetnya sudah ada pada hampir setiap rumah, sedangkan untuk beberapa daerah yang kondisi belum terlalu maju ataupun keadaan geografisnya tidak mendukung untuk jalur distribusi internet, warnet sangatlah jarang didapatkan dan mahal tarifnya jika ingin memasang di rumah sendiri. Pada daerah perkotaan sebuah warnet memiliki nama-nama umum panggilan lain seperti; Net Cafe, Cyber Cafe, atau Pusat Permainan Dalam Jaringan dimana sambungan internetnya dikhususkan untuk melakukan permainan komputer dalam jaringan.

Dalam tahun 2018 ini Game Online sudah menjadi salah satu cabang olang raga yang banyak di perlombakan, tidak hanya menjadi cabang olah raga, namun sudah 
menjadi pekerjaan bagi beberapa orang professional yang menekuni bermain game online. Dan untuk dapat bermain game yang tergolong dapat menjadi pekerjaan dan menghasilakan uang tidaklah gampang, karena spesifikasi dari game itu sangatlah tinggi, memaksa beberapa orang yang ingin serius dalam menekuni dunia game professional harus membeli perangkat personal computer ataupun laptop yang tidak murah, berikut beberapa harga Laptop maupun Personal Computer

\section{Kualitas Layanan}

Sinambela dkk (2010:6), mendefinisikan "kualitas adalah segala sesuatu yang mampu memenuhi keinginan atau kebutuhan pelanggan (meeting the needs of costumers)". Tjiptono (2004:11), mendefinisikan "kualitas sebagai kesesuaian untuk digunakan (fitness untuk digunakan). Definisi lain yang menekankan orientasi harapan pelanggan pertemuan".

Kadir (2001:19), Menyatakan bahwa "kualitas adalah tujuan yang sulit dipahami karena harapan para konsumen akan selalu berubah. Setiap standar baru ditemukan, maka konsumen akan menuntut lebih untuk mendapatkan standar baru lain yang lebih baru dan lebih baik. Dalam pandangan ini, kualitas adalah proses dan bukan hasil akhir".

Menurut Wyckof (Arief 2007:118) "kualitas jasa adalah tingkat keunggulan tersebut untuk memenuhi keinginan dan kebutuhan pelanggan. Baik tidaknya kualitas tergantung kepada kemampuan penyedia jasa pelayanan dalam memenuhi harapan pelanggan secara konsisten".

Menurut Gerson (2004:45), "kualitas adalah apapun yang dianggap pelanggan sebagai mutu". Sementara itu Kotler (2005:57) mendefinisikan "kualitas adalah keseluruhan sifat suatu produk atau pelayanan yang berpengaruh pada kemampuannya untuk memuaskan kebutuhan yang dinyatakan atau tersirat". Melalui Pengertian dan teori ini dapat diketahui bahwa suatu barang atau jasa akan dinilai bermutu apabila dapat memenuhi ekspektasi konsumen akan nilai produk yang diberikan kepada konsumen tersebut. Artinya, mutu atau kualitas merupakan salah satu faktor yang menentukan penilaian kepuasan konsumen. 


\section{Pengertian Layanan}

Menurut sinambela, (2014:4) "pelayanan adalah kegiatan untuk memenuhi kebutuhan seseorang atau menyediakan keperluan orang. Pelayanan juga merupakan suatu kegiatan atau urutan kegaiatan yang terjadi dalam interaksi langsung antar seseorang dengan orang lain atau mesin secara fisik dan menyediakan kepuasan pelanggan”. Menurut Philip Kotler $(2005 ; 153)$ "Kualitas pelayanan adalah model yang menggambarkan kondisi pelanggan dalam membentuk harapan akan layanan dari pengalaman masa lalu, promosi dari mulut kemulut, dan iklan dengan membandingkan pelayanan yang mereka harapkan dengan apa yang mereka terima atau rasakan”.

\section{Loyalitas Pelanggan}

Gramer and Brown sebagaimana yang dikutip oleh Mohammed (2013), memberikan definisi mengenai loyalitas yaitu derajat sejauh mana seorang konsumen menunjukkan perilaku pembelian berulang dari suatu penyedia jasa.

Menurut (Hasan,2014:134). "Loyalitas merupakan kondisi psikologis yang berkaitan dengan sikap terhadap produk, konsumen akan membentuk keyakinan, menetapkan suka dan tidak suka, dan memutuskan apakah mereka ingin membeli produk".

\section{Kepuasan Pelanggan}

Menurut (Lucia dan Maroco, 2013). "Kepuasan adalah perasaan senang karena mendapatkan hak - haknya dengan baik dan cenderung pada bentuk nyaman".

\section{Kerangka Berfikir}

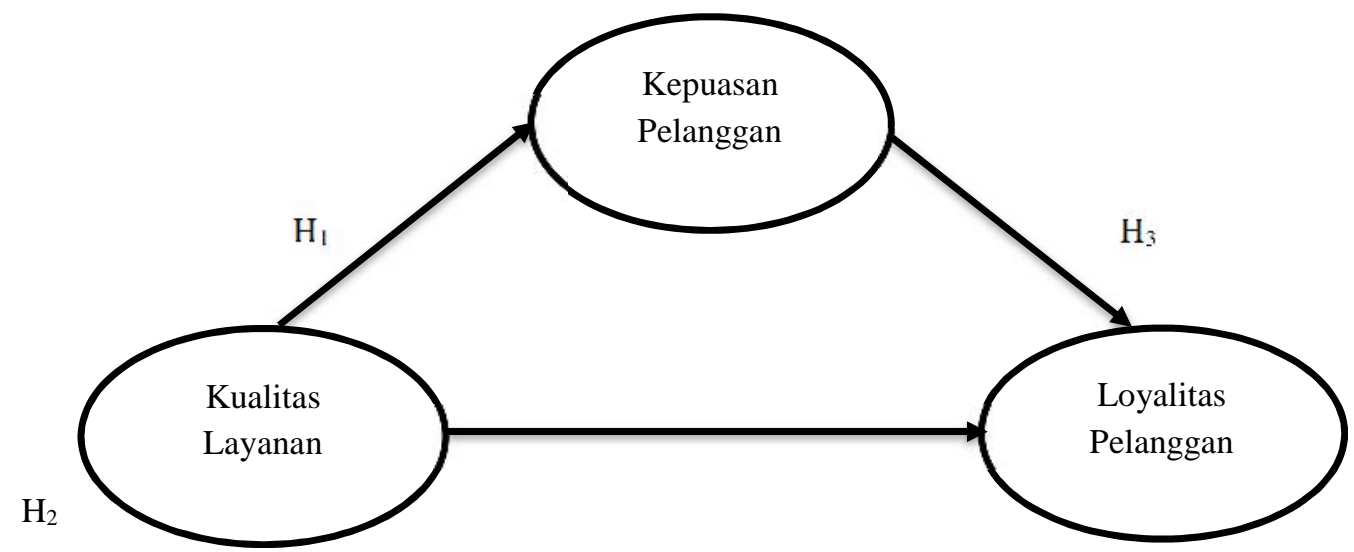

Sumber : Novandy, N.Rachma, Afif Rahmat Slamet ( 2017 ) 


\section{Hipotesis.}

Menurut Sugiono (2013:96) mengemukakan bahwa "hipotesis merupakan jawaban sementara terhadap rumusan masalah penelitian, dimana rumusan masalah penelitian telah dinyatakan dalam kalimat". Dengan demikian, berdasarkan kerangka berfikir pada gambar di atas, maka dapat ditarik hipotesis sebagai berikut :

$\mathrm{H}_{1}$ : Bahwa variabel Kualitas Layanan ( $\mathrm{X}$ ) memiliki pengaruh terhadap Kepusan Pelanggan pada Warnet I - Cafe di Kota Blitar.

$\mathrm{H}_{2}$ : Bahwa variabel Kualitas Layanan ( $\mathrm{X}$ ) memiliki pengaruh terhadap Loyalitas Pelanggan pada Warnet I - Cafe di Kota Blitar.

$\mathrm{H}_{3}$ : Bahwa variabel Kepuasan Pelanggan ( $\mathrm{Z}$ ) memiliki pengaruh terhadap Loyalitas Pelanggan pada Warnet I - Cafe di Kota Blitar.

$\mathrm{H}_{4}$ : Bahwa variabel Kualitas Layanan ( $\mathrm{X}$ ) memiliki pengaruh terhadap Loyalitas Pelanggan melalui Kepuasan Pelanggan pada Warnet I - Cafe di Kota Blitar.

\section{METODOLOGI}

\section{Sampel}

Sampel ialah bagian dari populasi yang diharpakan dapat mewakili keseluruhan populasi. Dapat dikatan juga, bahwa sampel merupakan bagian dari populasi yang ingin di teiti oleh peleniti. Menurut Sugiyono (2011:81)

\section{Metode Pengambilan Sampel}

"purposive sampling adalah teknik penentuan sampel dengan pertimbangan tertentu". Dari pengertian diatas agar memudahkan penelitian, penulis menetapkan sifat - sifat dan karakteristik yang digunakan dalam penelitian ini. Sampel yang akan di gunakan dalam penelitian ini memiliki ketentuan, pengunjung Warnet I - Cafe Kota Blitar, berjenis laki - laki dan perempuan yang berusia antara 17 tahun sampai dengan 25 tahun Menurut Sugiyono (2012:126)

\section{Definisi Operasional}

Menurut Sugiyono (2012: 31) Definisi operasional menjelaskan cara tertentu yang digunakan untuk meneliti dan mengoperasikan konstrak, sehingga memungkinkan bagi 
peneliti yang lain untuk melakukan replikasi pengukuran dengan cara yang sama atau mengembangkan cara pengukuran konstrak yang lebih baik.

\section{Metode Pengumpulan Data}

\section{Teknik Pengumpulan Data}

Teknik pengumpulan data yang digunakan dalam penelitian ini adalah kuesioner. Kuesioner merupakan angket yang disusun secara terstruktur guna menjaring data, sehingga diperoleh data akurat berupa tanggapan langsung responden. Sani dan Maharani (2013:184)

\section{Metode Analisis Data}

Dalam penelitian ini penulis menganalisa data dengan menggunakan analisis jalur (path analysis). Path analysis atau analisis jalur digunakan untuk menganalisis pola hubungan diantara variabel ( Sani dan Maharani, 2013:74). Model ini bertujuan untuk mengetahui pengaruh langsung maupun tidak langsung seperangkat variabel bebas (eksogen) terhadap variabel (endogen) riduwan dan kuncoro (2008) dalam Sani dan Maharani (2013:74).

\section{Hasil Penelitian}

\section{Pengujian Hipotesis H1}

Hipotesis H1 menyatakan bahwa Kualitas Layanan berpengaruh terhadap Kepuasan Pelanggan. Hasil uji terhadap koefisien parameter antara Kualitas Layanan terhadap Kepuasan Pelanggan menunjukkan adanya pengaruh yang positif sebesar 0,810 (berdasarkan nilai Original Sample Kualitas Layanan -> Kepuasan Pelanggan pada nilai 0,810 ) dengan nilai $\mathrm{T}$ statistic sebesar 16,666 dan signifikan pada $\alpha=0,05$. Nilai T statistic tersebut jauh di atas nilai kritis 1,98, dengan demikian hipotesis pertama dapat diterima.

\section{Pengujian Hipotesis H2}

Hipotesis H2 menyatakan bahwa Kualitas Layanan berpengaruh terhadap Loyalitas Pelanggan. Hasil uji terhadap koefisien parameter antara Kualitas Layanan terhadap Loyalitas Pelanggan menunjukkan adanya pengaruh positif sebesar 0,450 (berdasarkan 
nilai Original Sample Kualitas Layanan -> Loyalitas Pelanggan pada nilai 0,450) dengan nilai $\mathrm{T}$ statistic sebesar 2,767 dan signifikan pada $\alpha=0,05$. Nilai T nya jauh di atas nilai kritis 1,98 , dengan demikian hipotesis kedua diterima.

\section{Pengujian Hipotesis H3}

Hipotesis H3 menyatakan bahwa Kepuasan pelanggan berpengaruh terhadap Loyalitas Pelanggan. Hasil uji terhadap koefisien parameter antara Kepuasan Pelanggan terhadap Loyalitas Pelanggan menunjukkan adanya pengaruh positif sebesar 0,397 (berdasarkan nilai Original Sample Kepuasan Pelanggan -> Loyalitas Pelanggan pada nilai 0,397) dengan nilai $\mathrm{T}$ statistic sebesar 2,291 dan signifikan pada $\alpha=0,05$. Nilai $\mathrm{T}$ nya jauh di atas nilai kritis 1,98 , dengan demikian hipotesis ketiga diterima.

\section{Pengujian Hipotesis H4}

Hipotesis H4 menyatakan bahwa Kualitas Layanan berpengaruh terhadap Loyalitas Pelanggan melalui Kepuasan Pelanggan. Hasil uji terhadap koefisien parameter antara Kualitas Layanan terhadap Loyalitas Pelanggan melalui Kepuasan pelanggan menunjukkan adanya pengaruh positif sebesar 0,322 (berdasarkan nilai Original Sample Kualitas Layanan -> Kepuasan Pelanggan -> Loyalitas Pelanggan pada nilai 0,322) dengan nilai $\mathrm{T}$ statistic sebesar 2,308 dan signifikan pada $\alpha=0,05$. Nilai $\mathrm{T}$ nya jauh di atas nilai kritis 1,98, dengan demikian hipotesis keempat diterima.

\section{Pembahasan}

\begin{tabular}{|c|c|c|c|c|}
\hline Variabel & Langsung & $\begin{array}{c}\text { Melalui Kepuasan } \\
\text { Peanggan }\end{array}$ & Total & Keterangan \\
\hline $\begin{array}{c}\text { Kualitas Layanan -> } \\
\text { Loyalitas Pelanggan }\end{array}$ & 0,450 & $\begin{array}{c}\text { Berkurang } \\
0,130\end{array}$ & 0,320 & $\begin{array}{c}\text { Tidak menjadi } \\
\text { mediasai } \\
\text { sempurna }\end{array}$ \\
\hline $\begin{array}{c}\text { Kepuasan Pelanggan -> } \\
\text { Loyalitas Pelanggan }\end{array}$ & 0,392 & - & 0,392 & \\
\hline $\begin{array}{c}\text { Kualitas Layanan -> } \\
\text { Kepuasan Pelanggan }\end{array}$ & 0,810 & - & 0,810 & \\
\hline
\end{tabular}

Sumber : Hasil pengolahan data melalui SmartPLS 3 (2018) 
Hasil analisis jalur menunjukkan bahwa Kualitas Layanan secara langsung mempengaruhi Loyalitas Pelanggan sebesar 45,0\% dan mempengaruhi secara tidak langsung, yaitu dimediasi oleh Kepuasan Pelanggan sebesar 13,0\% secara tidak sempurna dan total pengaruh Kualitas Layanan terhadap Loyalitas Pelanggan menjadi 32,0\%. Dari data diatas diperoleh hasil bahwa Kepuasan Pelanggan tidak memiliki mediasi sempurna, karena adanya penurunan dari 45,0\% menjadi 32,0\% pengaruh yang dimiliki Kualitas Layanan terhadap Loyalitas Pelanggan melalui Kepuasan Pelanggan.

\section{KESIMPULAN DAN SARAN}

\section{Kesimpulan}

Kualitas Layanan memiliki pengaruh terhadap Kepuasan Pelanggan pada warnet I - Cafe di Kota Blitar. Hal ini menunjukan bahwa semakin banyak pelanggan yang sadar akan kualitas suatu layanan, Kualitas Layanan memiliki pengaruh terhadap Loyalitas Pelanggan pada warnet I - Cafe di Kota Blitar. Hal ini menunjukan bahwa semakin banyak pelanggan yang menjadi loyal dikarenakan oleh kualitas layanan,

Kepuasan Pelanggan memiliki pengaruh teradap Loyalitas Pelanggan pada warnet I - Cafe di Kota Blitar. Hal ini menjadi acuan untuk menikatkan kepuasan demi mendapatkan rasa loyal para pelanggan untuk menggunakan jasa warnet I - Cafe di Kota Blitar, Kualitas Layanan memiliki pengaruh terhadap Loyalitas Pelanggan melalui Kepuasan Pelanggan pada warnet I - Cafe di Kota Blitar dengan tingkat mediasi Kepuasan Pelanggan yang tidak sempurna. Jadi banyak pelanggan yang tidak perlu menunggu merasa puas untuk harus menjadi pelanggan yang loyal pada warnet I - Cafe di Kota Blitar.

\section{Saran}

Bagi warnet I - Cafe diharapkan mampu meningkatkan Kualitas Layanannya untuk para pelanggan dengan cara meningkatkan jumlah Personal Computer ( $P C$ ) supaya tidak harus lama menunggu. Tidak lupa

\section{DAFTAR PUSTAKA}

Arikunto, S. 2010. Prosedur Penelitian Suatu Pendekatan Praktis. Edisi Revisi 2010. Jakarta. Rineka Cipta. 
Arikunto, Suharsimi. 2013. Prosedur Penelitian Suatu Pendekatan Praktek. Rineka Cipta. Yogyakarta.

Alma, Buchari. 2005. Manajemen Pemasaran dan Pemasaran Jasa. Alfabeta. Bandung. Arikunto, Suharsimi. 2010. Prosedur Penelitian Suatu Pendekatan Praktis. Rineka Cipta. Jakarta.

Ruhamak, M. D., \& Rahayu, B. (2016). Pengaruh Word Of Mouth Terhadap Purchase Intention Melalui Brand Image Pada Lembaga Kursus Bahasa Inggris Dynamic English Course Pare. Jurnal Ekonomi Universitas Kadiri, 1(2), 188-204.

Satriyono, G., \& Ruhamak, M. D. (2017). Analisis Kesenjangan Antara Ekspektasi Konsumen Terhadap Persepsi Jasa Pelayanan (Studi Kasus Pada Bengkel Cat Dan Las Mobil Warna Indah Di Kediri). Ekonika: Jurnal Ekonomi Universitas Kadiri, 2(2), 142-151.

Diapinsa, Suwitho. 2017. Pengaruh Kualitas Pelayanan, Kualitas Produk dan Harga terhadap Kepuasan Pelanggan. Volume 6, Nomor 4, Halaman $1-18$.

Fandi Tjiptono. 2011. Kualitas Jasa Pengukuran, Keterbatasan dan Implikasi Manajerial. Majalah Manajemen Usahawan Indonesia. Jakarta.

Kotler, P. dan K. L. Keller. 2009. Manajemen Pemasaran. Edisi 13. Jilid 1. Erlangga. Jakarta.

Kristanti, D. (2018). KEBIJAKAN POTONGAN HARGA DAN VOLUME PENJUALAN, 16(2).

Ruhamak, M. D., \& Rahayu, B. (2016). Pengaruh Word Of Mouth Terhadap Purchase Intention Melalui Brand Image Pada Lembaga Kursus Bahasa Inggris Dynamic English Course Pare. Jurnal Ekonomi Universitas Kadiri, 1(2), 188-204.

Satriyono, G., \& Ruhamak, M. D. (2017). Analisis Kesenjangan Antara Ekspektasi Konsumen Terhadap Persepsi Jasa Pelayanan (Studi Kasus Pada Bengkel Cat Dan Las Mobil Warna Indah Di Kediri). Ekonika: Jurnal Ekonomi Universitas Kadiri, 2(2), 142-151.

Lupiyoadi, Rambat. 2001. Manajemen Pemasaran Jasa. Salemba Empat. Jakarta.

Novandy, N Rachma, Afif. 2017. Pengaruh Kualitas Pelayanan Terhadap Loyalitas Dengan Kepuasan Sebagai Variabel Intervening. Fakultas Ekonomi. Universitas Islam. Malang.

Parasuraman, A,.Valerie A. Zeithaml, and Leonard L. Berry. 1988."SERVQUAL: A Multiple Item Scalefor measuring Consumer Perception of Service Quality". Journal of Marketing. vol 64, p 12-40.

Rosa, A. dan D. Yunita. 2014. Analisis Kepuasan Penumpang Terhadap Kualitas Pelayanan Taksi Blue Bird Palembang. Vol 12 No.3, Hal 153-160.

Yulia, Hardi. 2017. Pengaruh Kualitas Pelayanan terhadap Loyalitas Pelanggan dengan Kepuasan sebagai Variabel Intervening (Studi Persepsi pada Pelanggan Dian Comp Ambarawa). Vol.10, No.19, Hal 70 - 90. 